Efficiency analysis of a solar photovoltaic array coupled with an electrolyser power unit: a case study

Peer-reviewed author version

SHIROUDI, Abolfazl; DELEUZE, Michael \& Mousavifar, Seyed Ahmad (2017) Efficiency analysis of a solar photovoltaic array coupled with an electrolyser power unit: a case study. In: International Journal of Ambient Energy, 38(3), p. 240-249.

DOI: $10.1080 / 01430750.2015 .1086676$

Handle: http://hdl.handle.net/1942/23223 


\title{
Efficiency analysis of a solar photovoltaic array coupled with an electrolyzer power unit: A case study
}

\author{
Abolfazl Shiroudi ${ }^{1,2 *}$, Michael S. Deleuze ${ }^{2}$, Seyed Ahmad Mousavifar ${ }^{1}$ \\ ${ }^{1}$ Ministry of Energy-Renewable Energy Organization of Iran (SUNA), Tehran, Iran \\ ${ }^{2}$ Center of Molecular and Materials Modelling, Hasselt University, Agoralaan, Gebouw D, B-3590 Diepenbeek, Belgium
}

\begin{abstract}
Hydrogen is one of the most promising and cleanest energy carriers, since it can be produced by water electrolysis. The efficiency of a solar $10 \mathrm{~kW}$ photovoltaic (PV) array consisting of 10 series-connected electrolyzer stacks and coupled with a $5 \mathrm{~kW}$ alkaline $(\mathrm{KOH}$, $28 \%$ ) electrolyzer has been investigated at the Taleghan renewable energies site in Iran. The hydrogen produced by the electrolyzer provides energy to a $1 \mathrm{~kW}$ polymer electrolyte membrane (PEM) fuel cell, which meets the load when the solar energy is insufficient. Variations of the solar radiation intensity, the hydrogen production rate, the solar hydrogen efficiency and the overall efficiency of the solar hydrogen energy unit were monitored in details. The overall energy efficiency was found to range from $0.93 \%$ to $5.01 \%$. The obtained results demonstrate the great potential of this power system for producing and storing energy in a solar-belt country like Iran.
\end{abstract}

Keywords: Solar Energy, Electrolyzer, Hydrogen Production, Energy Efficiency

\section{Nomenclatures}

AC: alternative current

DC: Direct current

RE: Renewable energy

PV: Photovoltaic system

SOC: State of charge

DOD: Depth of discharge

${ }^{*}$ Corresponding author: Tel: +32-488-980653

E-mail address: abolfazl.shiroudi@uhasselt.be (A. Shiroudi)

This paper is from conference proceeding of "World Renewable Energy Congress (WREC 2011)" 
E: Calorific value of hydrogen $(\mathrm{J} / \mathrm{ml})$

Q: Hydrogen production rate $(\mathrm{ml} / \mathrm{sec})$

$T_{\mathrm{c}}$ : PV cell temperature $\left({ }^{\circ} \mathrm{C}\right)$

$T_{\mathrm{r}}: \mathrm{PV}$ cell reference temperature $\left({ }^{\circ} \mathrm{C}\right)$

$v$ : Hydrogen production $\left(\mathrm{m}^{3} / \mathrm{hr}\right)$

$\mathrm{H}$ : Solar radiation intensity $\left(\mathrm{W} / \mathrm{m}^{2}\right)$

A: PV array surface $\left(\mathrm{m}^{2}\right)$

$\eta_{\text {overall: }}$ Overall system efficiency

PMU: Power management unit

$I_{\mathrm{e}}$ : The current between electrodes (A)

$\mathrm{S}$ : solar radiation intensity $\left(\mathrm{W} / \mathrm{m}^{2}\right)$

HHV: Hydrogen high heating value (142.92 MJ/kg $\approx 39.7 \mathrm{kWh} / \mathrm{kg})$

LHV: Hydrogen low heating value

HPR: Hydrogen production rate

PEM: Polymer exchange membrane

$\beta$ : Temperature coefficient of a solar cell in STC $\left(0.004{ }^{\circ} \mathrm{C}^{-1}\right)$

STC: Standard temperature conditions

\section{Introduction}

As conventional fossil fuel energy sources diminish and the world's environmental concern about acid deposition and global warming increases, renewable energy (RE) resources are attracting more and more attention as alternative energy sources. ${ }^{1}$ The use of RE resources, that do not endanger the environmental balance, is a way to solve many of the environmental problems caused principally by the excessive use of fossil fuels. RE resources are free of pollution during their development and operation for power generation. ${ }^{2} \mathrm{RE}$ systems based on intermittent sources exhibit strong seasonal variations in their energy outputs. Therefore, the need for storing energies in excess has become a most crucial economical and environmental issue. More specifically, new technologies are required for ensuring a full utilization of the available intermittent sources. With these technologies, one has ideally to store the energy produced in periods of low demand, so that it can be effectively released and used when the demand is high. ${ }^{3}$ Among the renewable energy sources, solar energy has been widely used in different applications, ${ }^{4}$ and is certainly one of the most promising candidates as renewable energy (RE) source, considering that fabrication on a large 
scale of photovoltaic cells has become economically and technologically feasible. ${ }^{1}$ To overcome intermittent problems due to the seasonal or daily variations of solar energy, energy storage mediums with greater longevity are required. Electricity can be stored through conversion to another energy form, such as chemical energy in batteries or as a green fuel like hydrogen. Each of the known energy storage options has advantages and disadvantages. Different factors need to be taken into account and compared from one storage option to the other, such as the environmental impact, the storage duration, the operating conditions, the form of the stored energy, the required energy density, the self discharge, the efficiency, the cost, etc.

Hydrogen is an ideal energy carrier, and, without doubts, the most efficient, cleanest and lightest fuels. The electrochemical decomposition of water into hydrogen and oxygen can be used to store energy, without emission of any dangerous byproducts (greenhouse gases like $\mathrm{CO}_{2}, \mathrm{CO}, \mathrm{HC}$, etc). ${ }^{5}$ When considering all the factors which need to be taken into account, the hydrogen storage option appears to be most advantageous, because of its particularly high efficiency, combined with very minimal environmental effects, ${ }^{6}$ its high energy content and storage compatibility. ${ }^{7-9}$ In addition, electrochemically produced hydrogen is expected to offset the seasonal variability of solar energy. ${ }^{8,10,11}$ The seasonal storage of solar energy in the form of a green fuel such as hydrogen can provide the basis for a completely renewable energy system. $^{12}$

There is a growing awareness that hydrogen is the fuel of the future, because hydrogen can be generated using different technologies. More specifically, hydrogen produced from solar energy is widely considered to be one of the best renewable and environmentally friendly energy carriers, and this for many reasons ${ }^{13}$ :

- Solar hydrogen technology is relatively simple; therefore, the cost of hydrogen as a fuel is expected to be substantially lower than that of the present price of gasoline.

- Water is the only raw material for production of solar hydrogen, and is a RE source.

- Large areas of the globe have access to solar energy, which is the only required energy source for solar hydrogen generation.

A country like Iran, with more than $4.5 \mathrm{kWh} / \mathrm{m}^{2} /$ day radiations, has a great potential for producing electricity from solar energy. ${ }^{14}$ The Iranian government is currently injecting massive amounts of money for constructing and piloting a solar hydrogen energy plant coupling a PV array to an electrolyzer-fuel cell at the Taleghan renewable energies (REs) site. 
The purpose of this study is to demonstrate the technical feasibility of the use of hydrogen as a solar energy storage medium. This small scale prototype energy system unit uses a photovoltaic (PV) array as the primary energy conversion technology, hydrogen as the energy storage medium, and a fuel cell as the electricity regeneration unit. ${ }^{15}$ A photography of the solar hydrogen energy unit which has been developed at the Taleghan REs site (Iran) is given in Figure 1.

\section{Description of the solar hydrogen energy system}

The studied energy system is located in a mountainous area, at the following latitude and longitude, $\mathrm{N} 36^{\circ}, 8^{\prime} / \mathrm{E} 50^{\circ}, 34^{\prime}$, respectively, and at an altitude of $1700 \mathrm{~m}$. This system consists of a $10 \mathrm{~kW} \mathrm{PV}$ array coupled to a $5 \mathrm{~kW}$ bipolar, alkaline electrolyzer, and a gas hydrogen storage tank. When sun shines, PV power is available and is used directly to supply the load while the electrolyzer turns on to begin producing hydrogen, which is delivered to the hydrogen storage tanks. On the contrary, when solar electricity is not available and the PV array cannot provide electricity, the $1.2 \mathrm{~kW}$ PEM fuel cell starts to produce electricity for the load using hydrogen taken from the hydrogen storage tank. ${ }^{16}$ The purpose of this study is to evaluate the overall efficiency of an alkaline electrolyzer matched to a solar PV source at the Taleghan REs site. A schematic depiction of the solar hydrogen energy system which has been constructed at this site is given in Figure 2.

\subsection{Photovoltaic array}

Solar radiation is a reliable source of energy that is received as a relatively diffuse form of energy. Its daily cycle varies and may be influenced greatly by meteorological conditions such as cloud, haze, and fog. Being a radiant form of energy, solar energy cannot be stored directly. Solar energy is one type of RE resources, which can be converted easily and directly to electrical energy by PV converters. PV devices convert solar radiation into electricity. ${ }^{17} \mathrm{PV}$ systems have the advantage of minimal maintenance requirements combined with the ease for expanding energy production capacities. PV systems also produce electricity at times of maximal demands, namely and most specifically on those hot sunny days which coincide with peak electricity consuming periods. ${ }^{18}$

The nominal operating temperature of the $\mathrm{PV}$ module is equal to $45^{\circ} \mathrm{C}$. At that temperature, the efficiency of the PV array under standard test condition is around $11.5 \%$. The specifications of the modules in the standard temperature conditions [STC] (i.e. under a radiation intensity of $1000 \mathrm{~W} / \mathrm{m}^{2}$ and a temperature of $25^{\circ} \mathrm{C}$ ) are listed in Table $1 .{ }^{19}$ 
A $10 \mathrm{~kW}$ PV array at the Taleghan renewable energies site consists of 224 solar panels corresponding to MA36/45 modules. The area of each module amounts to $0.45 \mathrm{~m}^{2}(46.2 \mathrm{~cm} \times$ $97.7 \mathrm{~cm})$. The total surface of the PV array is equal to $101.1 \mathrm{~m}^{2}\left(2 \times 7 \times 16 \times 0.45 \approx 101.1 \mathrm{~m}^{2}\right)$. The panels were mounted as fixed and tilted at $45^{\circ}$ with the horizontal plane, such that the module is facing the south direction (see Figure 3). The produced power depends on various factors, such as the temperature, the speed of wind, and the age of cells. The efficiency $\left(\eta_{\mathrm{e}}\right)$ of a solar cell varies as a function of the cell temperature $\left(T_{\mathrm{c}}\right)$, as follows:

$\eta_{e}=\eta_{r}\left[1-\beta\left(T_{c}-T_{r}\right)\right]$

where $\eta_{\mathrm{r}}$ is the efficiency of the cell under standard conditions, $T_{\mathrm{c}}$ denotes the PV cell temperature, $T_{\mathrm{r}}$ represents the reference temperature of the PV cell, and $\beta$ is the temperature coefficient of a solar cell in STC (the STC value for a PV module of polycrystalline silicon amounts to $\left.0.0004{ }^{\circ} \mathrm{C}^{-1}\right) .{ }^{20-21}$

The efficiency of the solar cell at hours ranging from 6 a.m. to 8 p.m. during a sample day at Taleghan RE site was monitored, according to the measured solar radiation intensity, the ambient temperature, and the temperature of the modules. Variations in times of basic parameters such as the solar radiation flux, the ambient temperature, the temperature of the modules, the power of the system, and the solar cell efficiency are displayed graphically in Figures 4 and 5.

\subsection{Battery bank}

Energy supply systems based on most natural RE sources (solar energy, wind, water flows, tides, ... etc) require energy storage by means of, for instance, electrochemical battery banks, because of inherent fluctuations in the supplied and consumed energies. ${ }^{18}$ This is particularly true for photovoltaic arrays. Due to the inherently variable nature of the electrical output of PV systems, energy storage is needed during periods of high bright sun in order to be able to supply the load "on demand". When the total outputs of the PV array exceed the energy demand, the battery bank is charged. ${ }^{14,22}$ On the contrary the battery bank releases electricity when needs by consumers exceed the electricity production. A complete analysis of the battery's charge and discharge requirements is required in order to adequately select the capacity and further characteristics of the battery bank.

Storage batteries developed by the Saba Battery Company ${ }^{23}$ were chosen for the present study. These batteries exhibit the following characteristics: a nominal voltage of $12 \mathrm{~V}$, a capacity of $100 \mathrm{Ah}$, along with an average lifetime of five years. The battery banks are made 
up of 48 deep discharge lead-acid batteries, resulting in a storage capacity of $57.6 \mathrm{kWh}$ (12 $\mathrm{V} \times 100 \mathrm{Ah} \times 48$ cell). The batteries are connected in series of battery strings, which consist of 12 batteries in each string. Each string of battery is capable of producing $14.4 \mathrm{kWh}$ of electricity. A photograph of the battery bank used at the Taleghan REs site is given in Figure 6. When the electrolyzer is turned off, the excess energy which is generated by the PV array is used to charge the batteries. If the excess energy is lower than the power required by the electrolyzer, the rest of the power needed to operate the electrolyzer is supplied by the batteries.

\subsection{Inverter}

A converter is required for a system in which DC components serve as an AC load or, inversely, in which AC components serve as a DC load. In other words, this converter operates as a rectifier that converts $\mathrm{AC}$ to $\mathrm{DC}$, or as an inverter that converts $\mathrm{DC}$ to $\mathrm{AC}$. The inverter used in this project is a Sunny Boy model 2500U. It is based on a power unit that operates with a high efficiency and optimal reliability. ${ }^{14}$ A $10 \mathrm{~kW}$ Sunny Boy $2500 \mathrm{U}$ model inverter is a single-phase AC power source that is connected between the battery bank and the utility grid at 195-251 $\mathrm{V}_{\mathrm{AC}}$. The operation of the inverter depends on the voltage level of the battery. The battery voltage decreases when the AC load increases. The Sunny Boy inverter is based on a power unit that operates with high efficiency and with optimal reliability (see Table 2). ${ }^{24}$

\subsection{Hydrogen unit}

Water electrolysis is a mature technology which has been used for numerous processes in the chemical industry for a long time. This process has particularly high energy efficiency for non-fossil fuel based hydrogen production, and is ideally suited for coupling with intermittent renewable energy sources. ${ }^{25}$ Water electrolysis is particularly suitable for storing energy produced by PV arrays. In general, good matches are found between the polarization curves of PV cells and water electrolysis. Nevertheless, the electricity produced by PV arrays is expensive and the hydrogen produced from such an electricity supply source is even more expensive. On the other hand, water electrolysis is a well developed and fully controlled technology, which could be rather easily used on a large scale for supplying electricity in discharge mode, or for hydrogen generation in charging mode. ${ }^{26}$ The electrochemical decomposition of water into hydrogen and oxygen occurs when a (DC) electric current 
circulates between two electrodes that are separated by an aqueous electrolyte. As is well known, the total reaction for electrochemically decomposing water is ${ }^{27}$ :

$$
\mathrm{H}_{2} \mathrm{O}(l)+\text { Electrical Energy } \underset{\text { charging mode }}{\stackrel{\text { discharging mode }}{\rightleftarrows}} \mathrm{H}_{2}(g)+\frac{1}{2} \mathrm{O}_{2}(g)
$$

The electrolyzer used at the Taleghan RE site has been manufactured by Hydrotechnik (Germany); it is bipolar and of the alkaline type. The electrolyzer module consists of 10 series-connected electrolyzer stacks. The nominal operating point is at a rated load of 250 amperes and at a maximal rated voltage of $25 \mathrm{~V}$. The chosen electrolyte is an aqueous solution of potassium hydroxide $(\mathrm{KOH})$ with a concentration of 28 wt.\%. The hydrogen production $v\left(\mathrm{~m}^{3} / \mathrm{s}\right)$ is proportional to the current $I_{\mathrm{e}}(A)$ passing through the electrolyzer, according to the formula:

$$
v=0.000419 \times I_{e} \times n=4.12 \times 10^{-3} \cdot I_{e} \quad\left(\mathrm{~m}^{3} / \mathrm{hr}\right)
$$

where $I_{\mathrm{e}}$ is the current (in Ampere), $n$ denotes the number of electrolytic cells, and $v$ represent the hydrogen production in $\mathrm{m}^{3} / \mathrm{hr}$. Hydrogen is stored at 10 bars in a tank to feed the fuel cell at low solar radiation levels and hence supply the required load power. ${ }^{28}$ Note that the efficiency is defined in terms of the hydrogen high heating value (HHV), where the products of the reactions are in liquid form, or the hydrogen low heating value (LHV), where the products are gaseous. The electrolyzer has a maximal power of $5 \mathrm{~kW}$ and yields about 1 $\mathrm{Nm}^{3} / \mathrm{hr}$ hydrogen gas under normal conditions, with a purity of $99.99 \%$. Under nominal conditions, the efficiency of the energy conversion process is around $70 \%$, based on $\mathrm{HHV}$ estimates:

$$
\begin{aligned}
& P_{\text {out }}=1\left(\frac{\mathrm{m}^{3}}{\mathrm{hr}}\right) \times \frac{1\left(\mathrm{~mol} \mathrm{H}_{2}\right)}{22.4(\mathrm{lit})} \times \frac{285830(\mathrm{~J})}{1\left(\mathrm{~mol} \mathrm{H}_{2}\right)} \times \frac{1(\mathrm{hr})}{3600(\mathrm{sec})} \times \frac{1000(\mathrm{lit})}{1\left(\mathrm{~m}^{3}\right)}=3544 \mathrm{~W} \\
& \eta=\frac{P_{\text {out }}}{P_{\text {in }}}=\frac{3544(\mathrm{~W})}{5000(\mathrm{~W})}=0.7089
\end{aligned}
$$

The oxygen gas which leaves the electrolyzer cells is far from being pure. The oxygen output of the electrolyzer still contains small amounts of hydrogen and vast amounts of water vapor. The oxygen output is not used in the power system and is simply released into the atmosphere. ${ }^{29-30}$ The hydrogen which is produced by the electrolyzer is sent into a lowpressure tank (buffer tank) which is kept at pressures that are lower than the hydrogen output pressure of the storage tank, as shown in Figure 7. An intermediate buffer reservoir is used so that the hydrogen compressor is run when sufficient excess energy is available. This buffer tank eliminates consumption of energy from the fuel cell or enlargement of the battery bank 
to power the hydrogen compressor. Compression occurs during diaphragm hydrogen compressor cycles, during which the hydrogen is continuously removed from the lowpressure tanks. These cycles begin at the current pressure of the low-pressure tank and end when the pressure drops to a specified minimum supply pressure. The volume of the hydrogen vessel is $1 \mathrm{~m}^{3}$ and the maximal pressure amounts to 10 bars (see Figure 8). This tank uses pressure relief valves, stainless steel piping and connectors, and one thermocouple that acts as a "gas gauge" determining the amount of gas in the tank. The stored hydrogen gas is used in the fuel cell.

\section{Results and Discussion}

The purpose of this study was to survey the overall efficiency of the solar hydrogen energy supply unit at the renewable energies site in Taleghan (Iran) on one specific day, from dawn to sunset. During this time interval, the electric current passing within the electrolyzer was found to increase from 0 to 250 amperes at midday time, prior to decreasing to 0 again after sunset. Electrical and process parameters such as the current, voltage, electrolyte inlet temperature, electrolyte outlet temperature, hydrogen production rate, the hydrogen and oxygen pressures within the electrolyzer were measured every 10 minutes. The overall efficiency of the direct coupling system has been calculated on the ground of these data, according to the following formule: ${ }^{31}$

$$
\eta_{\text {overall }}=\frac{Q \cdot E}{S \cdot A}
$$

where $A$ is the total surface of the PV array $\left(\mathrm{m}^{2}\right), Q$ denotes the hydrogen production rate $(\mathrm{ml} / \mathrm{sec}), E$ represents the calorific value of hydrogen $(\mathrm{J} / \mathrm{ml})$, and $S$ is the solar radiation flux $\left(\mathrm{W} / \mathrm{m}^{2}\right)$.

Among all known fuels, hydrogen gas has the highest calorific value, which amounts to $150 \mathrm{~kJ} / \mathrm{g}(\approx 12.6 \mathrm{~J} / \mathrm{mol}) .{ }^{32} \mathrm{We}$ presumed that water electrolysis operated during a sample day in summer during 150 minutes (10:30 a.m. to 12:50 p.m.). The overall efficiency of the solar hydrogen energy system during this time interval has been determined based on all the parameters that are listed and quantified in Table 3.

Figure 4 shows the solar radiation intensity and power system recorded on the sample day, while the corresponding cell temperature and photovoltaic efficiency are shown in Figure 5. Variations of the solar radiation intensity and solar hydrogen efficiency as a function of time (from 10:30 a.m. until 12:50 p.m.) are shown in Figure 9; variations of the produced hydrogen flow rate and solar hydrogen energy efficiency versus solar radiation intensity are 
correspondingly shown in Figures 10 and 11. Upon inspecting these figures, it is clear that the PV array current is directly affected by the solar radiation intensity. Furthermore, environmental parameters such as the solar radiation intensity, the ambient temperature and the PV cell temperature are found to have a large effect on the performance of the energy system and on the rate of hydrogen production. Obviously, increases of the solar radiation intensity correlated with increases of the electric current passing through the electrolyzer, which in turn correlate with increases of the rate of hydrogen production (Table 3).

\section{Conclusions}

A renewable energy system consisting of an alkaline electrolyzer $(5 \mathrm{~kW})$ coupled with a photovoltaic array $(10 \mathrm{~kW})$ and a hydrogen gas storage vessel $\left(1 \mathrm{~m}^{3}\right)$ has been tested at the Taleghan renewable energies site (Iran). The coupling of $10 \mathrm{~kW} \mathrm{PV}$ arrays with a $5 \mathrm{~kW}$ alkaline electrolyzer system allows converting and storing at high efficiency the produced electricity into electrochemically stable energy carriers. Using a fuel cell to get back electricity induces a lower efficiency but allows building a silent energy generator consuming no raw materials. The effects of hydrogen production rate and solar radiation on the overall efficiency have been studied in details (Figure 2). The overall efficiency was found to range from $0.93 \%$ to $5.01 \%$. The latter values coincide (Table 3 ) with an increase in current from 25 to 250 amperes, an increase from the module temperature from 34 to $41^{\circ} \mathrm{C}$, and an increase of the hydrogen production rate from 9 to $15.5 \mathrm{lit} / \mathrm{min}$, from the early morning until about midday on the sample day.

The replacement of conventional technologies (batteries) by hydrogen technologies is technologically feasible, and will reduce pollutants and $\mathrm{CO}_{2}$ emissions, noise and dependence upon fossil fuels; it will also increase renewable energy supplies. A country like Iran, which is ideally located on the solar belt, has a great potential for producing electricity directly from natural solar radiation energy, and converting it to other types of energy. Using solar energy requires high initial investments. However, converting with high efficiency a most abundant form of energy such as the solar energy into physico-chemically stable forms of energy is most obviously vital for the future of mankind.

\section{Acknowledgement}

A. Shiroudi acknowledges financial support by the Ministry of Energy-Renewable Energy Organization of Iran (SUNA), as well as a $\mathrm{PhD}$ fellowship from the "Bijzonder Onderzoeksfonds" (BOF) of Hasselt University (Belgium). 


\section{References}

[1] Ro, K., and S. Rahman. 1998. "Two-Loop Controller for Maximizing Performance of a Grid-Connected Photovoltaic-Fuel Cell Hybrid Power Plant." IEEE Transactions on Energy Conversion 13: 276-281.

[2] Ramirez, A. M., Sebastian, P. J., Gamboa, S. A., Rivera, M. A., Cuevas, O., and J. Campos. 2000. “A Documented Analysis of Renewable Energy Related Research and Development in Mexico.” International Journal of Hydrogen Energy 25: 267-271.

[3] Isherwood, W., Smith, J. R., Aceves, S. M., Berry, G., Clark, W., Johnson, R., Das, D., Goering, D., and R. Seifert. 2000. "Remote Power Systems with Advanced Storage Technologies for Alaskan Villages.” Energy 25: 1005-1020.

[4] Bahgat, A. B. G., Helwa, N. H., Ahamd, G. E., and E. T. El Shenawy. 2004. "Estimation of the Maximum Power and Normal Operating Power of a Photovoltaic Module by Neural Networks." Renewable Energy 29: 443-457.

[5] Conibeer, G. J., and B. S. Richards. 2007. "A Comparison of PV/Electrolyzer and Photoelectrolytic Technologies for Use in Solar to Hydrogen Energy Storage Systems.” International Journal of Hydrogen Energy 32: 2703-2711.

[6] Yilanci, A., Dincer, I., and H. K. Ozturk. 2009. “A Review on Solar-Hydrogen/Fuel cell Hybrid Energy Systems for Stationary Applications." Progress in Energy and Combustion Science 35: 231-244.

[7] Momirlan, M., and T. N. Veziroglu. 1999. "Recent Directions of World Hydrogen Production.” Renewable and Sustainable Energy Reviews 3: 219-231.

[8] Momirlan, M., and T. N. Veziroglu. 2002. "Current Status of Hydrogen Energy." Renewable and Sustainable Energy Reviews 6: 141-179.

[9] Midilli, A., Ay, M., Dincer, I., and M. A. Rosen. 2005. "On Hydrogen and Hydrogen Energy Strategies: I: Current Status and Needs." Renewable and Sustainable Energy Reviews 9: 255-271.

[10] Padró, C. E. G., and V. Putsche. 1999. Survey of the Economics of Hydrogen Technologies. National Renewable Energy Laboratory report No: NREL/TP-570-27079, p. $1-57$.

[11] Harriman, A., and M. A. West. 1982. Photogeneration of Hydrogen. New York: Academic Press.

[12] Ulleberg, Ø. 2004. "The Importance of Control Strategies in PV-Hydrogen Systems." Solar Energy 76: 323-329. 
[13] Nowotny, J., Sorrell, C. C., Sheppard, L. R., and T. Bak. 2005. "Solar-Hydrogen: Environmentally Safe Fuel for the Future.” International Journal of Hydrogen Energy 30: $521-544$.

[14] Shiroudi, A., Rashidi, R., Gharehpetian, G. B., Mousavifar, S. A., and A. Akbari Foroud. 2012. "Case study: Simulation and Optimization of Photovoltaic-Wind-Battery Hybrid Energy System in Taleghan-Iran Using HOMER Software." Journal of Renewable and Sustainable Energy 4: 53111-53121.

[15] Galli, S., and M. Stefanoni. 1997. "Development of a Solar-Hydrogen Cycle in Italy." International Journal of Hydrogen Energy 22: 453-458.

[16] Nelson, D. B., Nehrir, M. H., and C. Wang. 2006. "Unit Sizing and Cost Analysis of Stand-Alone Hybrid Wind/PV/Fuel cell Power Generation Systems.” Renewable Energy 31: $1641-1656$.

[17] Shiroudi, A., Hosseini Taklimi, S. R., Mousavifar, S. A., and P. Taghipour. 2013. "Stand-alone PV-Hydrogen energy system in Taleghan-Iran using HOMER software: Optimization and techno-economic analysis," Environ Dev Sustain. 15: 1389-1402.

[18] Karakoulidis, K., Mavridis, K., Bandekas, D. V., Adoniadis, P., Potolias, C. and N. Vordos. 2001. "Techno-Economic Analysis of a Stand-Alone Hybrid PhotovoltaicDiesel-Battery-Fuel Cell Power System.” Renewable Energy 36: 2238-2244.

[19] Technical Catalogue of Solar Module MA36/45, Optical Fiber Fabrication Company, Iran.

[20] Siegel, M. D., Klein, S. A., and W. A. Beckman. 1981. "A Simplified Method for Estimating the Monthly-Average Performance of Photovoltaic Systems." Solar Energy 26: 413-418.

[21] Soras, C., and V. Makios. 1988. "A Novel Method for Determining the Optimum Size of Stand-Alone Photovoltaic Systems.” Solar Cells 25: 127-142.

[22] Mirhosseini, M., Sharifi, F., and A. Sedaghat, 2011. "Assessing the Wind Energy Potential Locations in Province of Semnan in Iran." Renewable and Sustainable Energy Reviews 15: 449-459.

[23] See www.sababattery.ir for Saba Batteries Company.

[24] See www.SMA.de for SMA Solar Technology AG Company.

[25] Cox, K. E., and K. D. Williamson. 1977. Hydrogen: Its Technology and Implications. CRC Press, Cleveland, Ohio, USA. 
[26] Sherif, S. A., Barbir, F., and T. N. Vezirouglu. 2005. "Wind Energy and the Hydrogen Economy-Review of the Technology." Solar Energy 78: 647-660.

[27] Khan, M. J., and M. T. Iqbal. 2005. "Dynamic Modeling and Simulation of a Small Wind-Fuel cell Hybrid Energy System.” Renewable Energy 30: 421-439.

[28] El-Shatter, Th. F., Eskandar, M. N., and M. T. El-Hagry. 2002. "Hybrid PV/Fuel cell System Design and Simulation.” Renewable Energy 27: 479-485.

[29] Hollmuller, P., Joubert, J., Lachal, B., and K. Yvon. 2000. "Evaluation of a $5 \mathrm{~kW}_{\mathrm{p}}$ Photovoltaic Hydrogen Production and Storage Installation for a Residential Home in Switzerland." International Journal of Hydrogen Energy 25: 97-109.

[30] Perez, R. 1991. "The Schatz PV hydrogen project.” Home Power. 22: 26-30.

[31] Ahmad, G. E., and E. T. El Shenawy. 2006. "Optimized Photovoltaic System for Hydrogen Production.” Renewable Energy 31: 1043-1054.

[32] See http://home.att.net/ cat6a/fuels-VII.htm. 


\section{Figure captions}

Fig. 1. Photography of the solar hydrogen unit power system at Taleghan REs site.

Fig. 2. Schematic depiction of the solar hydrogen unit power system at the Taleghan REs site.

Fig. 3. Photography of the photovoltaic array installed at the Taleghan REs site.

Fig. 4. Variations in time of the solar radiation intensity and power of the PV array during the sample day.

Fig. 5. Variations in time of the efficiency of the PV array and of the cell temperature during the sample day.

Fig. 6. Photography of the battery bank in the solar hydrogen power system.

Fig. 7. Schematic depiction of the hydrogen storage system.

Fig. 8. Photography of the $5 \mathrm{~kW}$ alkaline electrolyzer in the solar hydrogen power system.

Fig. 9. Variations in time of the solar radiation intensity and of the solar hydrogen efficiency during the sample day.

Fig. 10. Dependence of the hydrogen production rate upon the solar radiation intensity.

Fig. 11. Dependence of the solar hydrogen system efficiency upon the solar radiation intensity. 
Table 1. Electrical characteristics of a single photovoltaic module (MA36/45)

\begin{tabular}{lc}
\hline Parameters & Values \\
\hline Nominal power & $45 \mathrm{~W}$ \\
Nominal load voltage & $20.5 \mathrm{~V}$ \\
Voltage in maximum power point & $16.7 \mathrm{~V}$ \\
Short circuit current & $2.96 \mathrm{~A}$ \\
Current at maximum power point & $2.74 \mathrm{~A}$ \\
Nominal efficiency & $11.5 \%$ \\
\hline
\end{tabular}

Table 2. Technical characteristics of the Inverter (Sunny Boy model 2500)

\begin{tabular}{lc}
\hline SUNNY BOY $\quad$ TYPE & 2500 \\
\hline $\mathrm{P}_{\text {nominal }}$ & $2200 \mathrm{~W}_{\mathrm{P}}$ \\
Max input voltage $\left(\mathrm{V}_{\mathrm{DC}}, \mathrm{max}\right)$ & $600 \mathrm{~V}$ \\
PV-Voltage MPPT $\left(\mathrm{V}_{\mathrm{pv}}\right)$ & $250-600 \mathrm{~V}$ \\
Max input current & $11.2 \mathrm{~A}$ \\
$\mathrm{P}_{\max }$ & $2500 \mathrm{~W}$ \\
Peak Inverter Efficiency & $93-94.4 \%$ \\
AC Input Frequency & $49.8-50.2 \mathrm{~Hz}$ \\
$\mathrm{~V}_{\mathrm{AC}}$ & $198-251 \mathrm{~V}$ \\
\hline
\end{tabular}

Table 3. Evolution in time of the output of the studied power supply unit, and of environmental parameters.

\begin{tabular}{cccccccc}
\hline Time & $\begin{array}{c}\text { Voltage } \\
(\mathrm{V})\end{array}$ & $\begin{array}{c}\text { Current } \\
(\mathrm{A})\end{array}$ & $\begin{array}{c}\text { Hydrogen } \\
\text { production rate } \\
(\text { lit/min })\end{array}$ & $\begin{array}{c}\text { Insolation } \\
\left(\mathrm{W} / \mathrm{m}^{2}\right)\end{array}$ & $\begin{array}{c}\text { Ambient } \\
\text { temp }\left({ }^{\circ} \mathrm{C}\right)\end{array}$ & $\begin{array}{c}\text { Module } \\
\text { temp. }\left({ }^{\circ} \mathrm{C}\right)\end{array}$ & $\begin{array}{c}\text { Overall } \\
\text { efficiency } \\
\text { system }(\%)\end{array}$ \\
\hline 10:30 a.m. & 20.2 & 25 & 9.0 & 615 & 23 & 34 & 0.93 \\
10:40 a.m. & 21.4 & 50 & 9.2 & 632 & 23 & 35 & 1.70 \\
10:50 a.m. & 21.8 & 75 & 9.5 & 645 & 23.5 & 36 & 2.39 \\
11:00 a.m. & 22.3 & 100 & 10.2 & 676 & 24 & 38 & 2.92 \\
$11: 10$ a.m. & 22.6 & 125 & 10.5 & 688 & 24 & 38.5 & 3.41 \\
$11: 20$ a.m. & 22.7 & 137.5 & 10.7 & 696 & 24.5 & 39 & 3.56 \\
11:30 a.m. & 22.8 & 150 & 11 & 708 & 24.5 & 39 & 3.77 \\
$11: 40$ a.m. & 22.9 & 162.5 & 11.5 & 717 & 24.5 & 39.5 & 4.01 \\
$11: 50$ a.m. & 23 & 175 & 12 & 727 & 25 & 40 & 4.18 \\
12:00 noon & 23.1 & 187.5 & 12.5 & 738 & 25 & 40 & 4.33 \\
12:10 p.m. & 23 & 200 & 13 & 736 & 26 & 40 & 4.41 \\
12:20 p.m. & 22.8 & 212.5 & 13.5 & 734 & 26.5 & 40 & 4.49 \\
12:30 p.m. & 22.7 & 225 & 14 & 732 & 26.5 & 40 & 4.67 \\
12:40 p.m. & 22.4 & 237.5 & 15 & 730 & 27 & 40.5 & 4.79 \\
12:50 p.m. & 21.7 & 250 & 15.5 & 728 & 27 & 41 & 5.01 \\
\hline
\end{tabular}


